\title{
Age, Sex and Body Weight Related Echocardiographic Parameters of Clinically Healthy New Zealand White Rabbits*
}

\author{
Omer Gurkan Dilek' \& Hasan Erden²
}

\begin{abstract}
Background: Echocardiography provides useful additional information on cardiac dimensions including heart wall and dimension of the ventricles, atria and conditions. Rabbits have been diagnosed with cardiac diseases, and an understanding of the animals' cardiac chamber dimensions is vital in assessing the diseases' severity and prognoses. Changes in cardiac dimensions due to age related and body weight were determined at different animals. The increased incidence of congenital cardiovascular anomalies makes it essential to establish the diagnosis at an early age. The aims of this study 1) establish normal values for the commonly used two-dimensional (2D) M-mode parameters using pre anaesthetics and 2) evaluate the effects of age, sex, and body weight on echocardiographic parameters in clinically healthy New Zealand rabbits.

Materials, Methods \& Results: In this study we used 49 New Zealand white rabbits (25 male, 24 female) all reared under the same conditions. A general physical and clinical examination including complete blood count was performed for each animal. Body surface area was calculated as BSA $=0.00718 \times$ Height $^{0.725} \times$ Weight ${ }^{0.425}$. Rabbits were sedated with midazolam before echocardiographic examination was performed. Echocardiographic examination was performed using a DC 6-Vet ${ }^{\circledR}$ (Mindray, PRC) ultrasonographic device equipped with a micro-convex $8 \mathrm{MHz}$ probe. Right parasternal shortaxis view, B-mode and two-dimensional guided M-mode parameters were measured. Echocardiographic measurements were performed using leading-edge-to-leading-edge conventions outlined by the American Society of Echocardiography. Statistical analyses were employed using the SPSS 19.0 program. Sex had no significant effect on the measured echocardiographic parameters except in the case of interventricular septum thickness in diastole values of the three-month-old rabbits. The increase in the left ventricular systolic and diastolic diameters, E- point to septal separation, diastolic aortic root parameters for the three, six, and nine-month-old groups indicated persistent anatomic heart enlargement. However, it was also discovered that the fractional shortening percentage of the left ventricle and diastolic diameters of left atrium:aortic root were unrelated to age and weight.

Discussion: New Zealand rabbits are an important model for cardiovascular research, mainly as they are small and relatively inexpensive however large enough to allow anatomical and physiological experiments. Different ages and sizes of New Zealand rabbits showed no significant difference in fractional shortening despite heart enlargement. The ejection fraction, which can be calculated from the left ventricular dimensions via M-mode echocardiography, is another parameter of cardiac function. Our echocardiograph calculated the ejection fraction automatically using the Teicholz formula. It was further observed that three-month-old rabbits ejection fraction of the left ventricle was higher than that of the six and nine-month-old rabbits. This might indicate the necessity of periodical analysis of echocardiographic parameters. Transthoracic echocardiography can be considered an applicable method for cardiovascular research using a growing rabbit animal model after appropriate adjustments for age, sex and body size. These findings give a better understanding of the functional changes investigated by echocardiography in rabbits and will be helpful when evaluating echocardiographic data in small experimental animals.
\end{abstract}

Keywords: rabbit, heart, left ventricle function, ejection fraction. of Veterinary Medicine, University of Burdur Mehmet Akif Ersoy, Burdur, Turkey. ${ }^{2}$ Department of Anatomy, Faculty of Veterinary Medicine, University of Adnan Menderes, Aydın, Turkey. CORRESPONDENCE: O.G. Dilek [ogdilek@ gmail.com - Tel.: +90 505371 8722]. Department of Anatomy, Faculty of Veterinary Medicine, University of Burdur Mehmet Akif Ersoy. TR-15030 Burdur, Turkey. 


\section{INTRODUCTION}

Body weight (BW), body surface area (BSA), and age can affect cardiac dimensions and function $[1,31,35]$. Many studies have been conducted to establish the relationship between cardiac dimensions and body weight in horses, dogs, cats, sheep and rats $[1,4,10,19,28,32,35]$. Casamian-Sorrosal et al. [5] studied the echocardiographic parameters of Dwarf Lops, French Lops and Alaskan rabbits. Fontes-Sousa et al. and Mora et al. [13,25] studied the same parameters among New Zealand White Rabbits. The rabbits in these studies were constantly under the influence of both sedatives and anaesthetic agents, which can affect echocardiographic measurements [38]. Additionally, it was speculated $\alpha 2$-adrenergic receptor agonists effect the echocardographic values and it is possible that their results would differ from those obtained in conscious rabbits [13]. According to our knowledge there are no normative echocardiographic values on rabbits at different age, sex and body weight using pre anaesthetics. The goals of this study are to 1) establish normal values for the commonly used two-dimensional (2D) M-mode parameters using pre anaesthetics and 2) evaluate the effects of age, sex, and body weight on echocardiographic parameters in clinically healthy New Zealand rabbits.

\section{MATERIALS AND METHODS}

\section{Animals}

We used a total of 49 New Zealand rabbits, male and female, of three different ages: three months, including nine males (group 1) and seven females (group 2); six months, with eight males (group 3) and nine females (group 4); and nine months, of which eight were males (group 5) and eight were females (group 6). These rabbits were obtained from the Experimental Animals Breeding Department of Mehmet Akif Ersoy University, Burdur, Turkey. The rabbits were housed in stainless steel cages in a controlled environment at temperatures of 20 to $25^{\circ} \mathrm{C}$ with a 12:12-h light-dark cycle, and were fed a standard pellet diet and water ad libitum. The rabbits were healthy and showed no signs of cardiovascular or respiratory tract disease following a physical examination that included careful thoracic auscultation and assessments of heart rate, body temperature, capillary refill time, and mucous membranes. After the physical examinations, erythrocytic parameters (red blood cell, hemoglobin, hemotocrit, mean cell volume, mean cell hemoglobin, mean cell hemoglobin concentration, red cell distribution width) were performed to determine if there were any signs of anemia. Age, sex, weight, and BSA were recorded for each rabbit. BSA was calculated using method [11]:

$$
\mathrm{BSA}=0.00718 \times \text { Height }^{0.725} \times \text { Weight }^{0.425}
$$

\section{Echocardiography}

The examination was conducted under light anaesthesia; the animals were anaesthetised by intramuscular injection of a midazolam $\left(\text { Dormicum }^{\circledR}\right)^{1}$ and allowed to breathe spontaneously. Transthoracic 2D M-mode echocardiography was performed using a commercially available digital cardiac ultrasound platform equipped with an $8 \mathrm{MHz}$ short focal-length micro convex transducer (DC 6-Vet $\left.{ }^{\circledR}\right)^{2}$. The rabbits were placed in right lateral recumbency to obtain right parasternal views, and the age, sex, BSA, and weight were recorded for each subject. Echocardiography was stopped if a rabbit was observed to be very stressed.

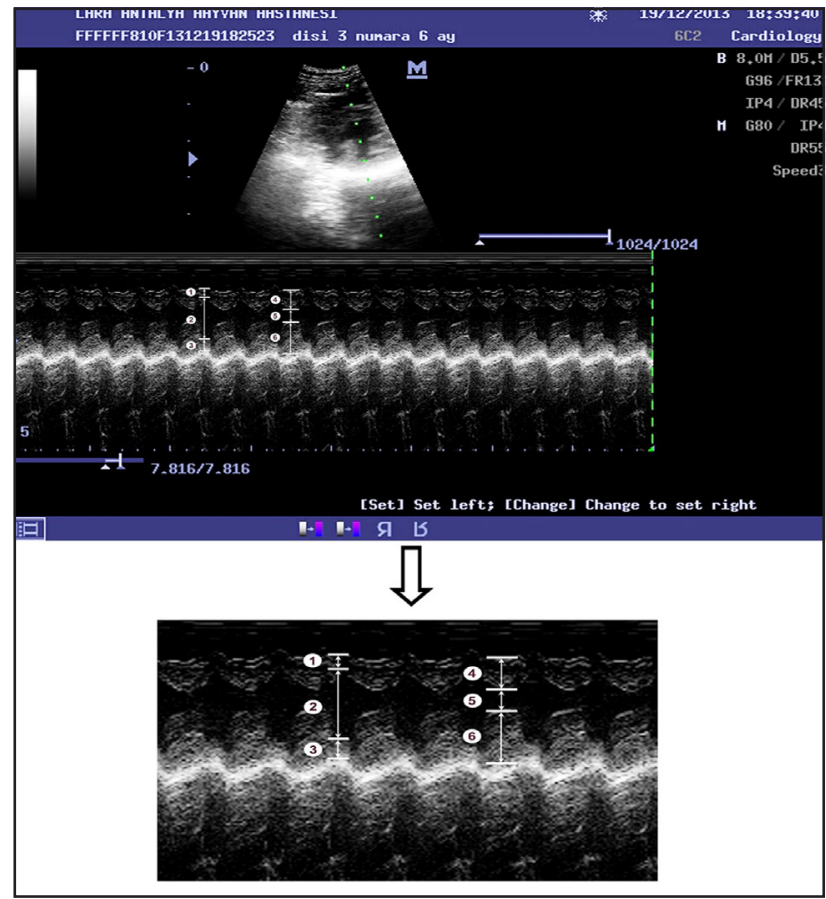

Figure 1. Right parasternal short-axis view of the papillary muscle. 1: Interventricular septum thickness in diastole, 2: Left ventricular internal diameter at end-diastole, 3: Left ventricular posterior wall thickness in diastole, 4: Interventricular septum thickness in systole, 5: Left ventricular internal diameter at end-systole, 6: Left ventricular posterior wall thickness in systole.

Echocardiographic examination and measurements were acquired following the standard protocols defined for small animals [3]. These measurements were obtained in the right parasternal short-axis view 
of the papillary muscle (Figure 1), the right parasternal view of the heart base and aorta (Figure 2), and the right parasternal view of the atrioventricular valve. The measurements included interventricular septum in diastole (IVSTd) and systole (IVSTs), left ventricular internal diameter at end-diastole (LVIDd) and endsystole (LVIDs), and left ventricular posterior wall thickness in diastole (LVPWd) and systole (LVPWs). Cross-sectional left atrial (LAd) and aortic root (AOd) diameters were determined and ratio of LA to AO was calculated using these data [30]. The right parasternal short-axis mitral valve level view was used for to measure the E-point septal separation (EPSS) interval in the mitral valve plane. Echocardiographic measurements were performed using leading-edge-to-leadingedge conventions outlined by the American Society of Echocardiography [34]. Fractional shortening was computed using the equation [(LVIDd - LVIDs) / LVIDd] $\times 100 \%$, and ejection fraction was calculated using the Teichholz formula [39]. The specimens' pointwise measurements were replicated three times for each rabbit.

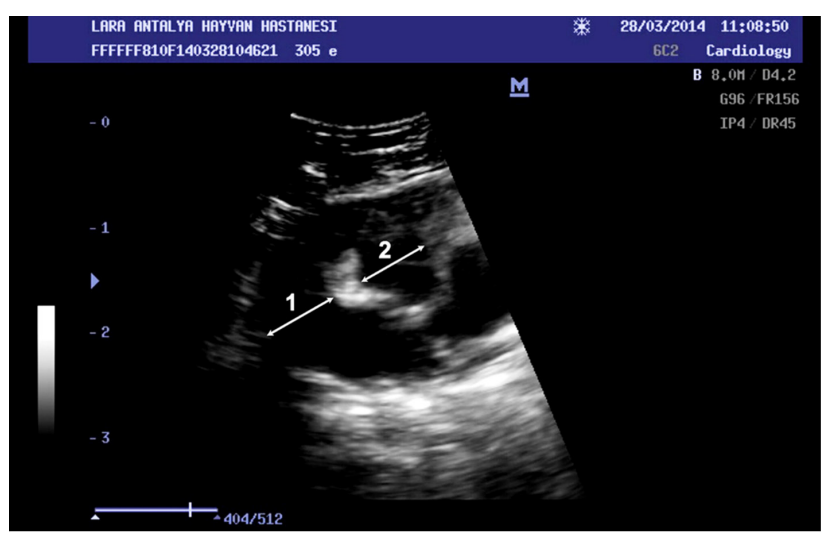

Figure 2. Right parasternal short-axis view of the aortic valve. 1: Crosssectional left atrial diameter, 2: Aortic root diameter.

\section{Statistical analysis}

Statistical analyses were performed using SPSS software, version 19.0, for Windows ${ }^{3}$. The data are reported as means, standard deviations (SDs), and ranges. Blood count and echocardiographic parameters are reported as means, standard deviations (SDs), and $95 \%$ confidence intervals. A one-way analysis of variance (ANOVA) was used to test the effects of age or body weight on echocardiographic parameters and the Bonferroni test was used in post hoc analysis to determine whether these differences were significant. The differences between male and female rabbits were analysed using the student $t$-test. For the non-parametric distribution, Mann-Whitney tests were used. Pearson correlation analysis was conducted to assess whether the rabbits' weight and age differences were related to differences in their echocardiographic parameters. The level of significance was set to $(P<0.05)$ for all analyses.

\section{RESULTS}

\section{Physical and clinical examination}

All the rabbits were in good health following physical examination, and all their haematological parameters were within the reference ranges. During the procedure no significant changes from baseline values were observed in any rabbit. The mean BW was 2018 $\pm 173.45 \mathrm{~g}$ and $4413 \pm 355.45 \mathrm{~g}$ at the beginning and end of the study, respectively. There were no significant differences in heart rate or body temperature between the different age groups, though body weight, BSA, body length, and chest circumference did vary significantly between age groups. There were no significant differences in age, body temperature, or heart rate along sex lines (Table 1).

The hematocrit value on this study: Group $1=$ $41.53 \% \pm 2.89$, group $2=41.37 \% \pm 2.54$, group $3=$ $46.29 \% \pm 5.02$, group $4=44.98 \% \pm 3.84$, group $5=$ $48.67 \% \pm 3.85$, group $6=47.67 \% \pm 1.69$. It was also found that the hematocrit value of male rabbits was slightly higher than that of female rabbits in all age groups.

\section{Effect of age and body weight on echocardiographic parameters}

Table 2 shows the P-values obtained for the age and echocardiographic parameters of the rabbits. IVSTd, LVIDd, LVPWd, IVSTs, LVIDs, LVPWs, EPSS, EF\%, LAd, and AOd were varied significantly as a function of age and body weight. FS\% was 34.43 $\pm 3.88,32.39 \pm 2.49$ and $31.39-33.60$ respectively age groups. Lad:AOd was $1.17 \pm 0.03,1.20 \pm 0.03$ and $1.18 \pm 0.05$ respectively in age groups. The differences in FS\% and Lad:AOd were not statistically significant. Table 3 shows the $\mathrm{P}$-values obtained for each sex and age and the related echocardiographic parameters. 
O.G. Dilek \& H. Erden. 2019. Age, Sex and Body Weight Related Echocardiographic Parameters of Clinically Healthy New Zealand White Rabbits. Acta Scientiae Veterinariae. 47: 1652.

Table 1. The clinical characteristics and circumferential measurements of the age groups.

\begin{tabular}{|c|c|c|c|c|c|c|}
\hline Group & $\begin{array}{l}\text { Body weight } \\
(\mathrm{g})\end{array}$ & $\begin{array}{l}\text { BSA } \\
\left(\mathrm{m}^{2}\right)\end{array}$ & $\begin{array}{l}\text { Body length } \\
\quad(\mathrm{cm})\end{array}$ & $\begin{array}{c}\text { Chest } \\
\text { circumference }(\mathrm{cm})\end{array}$ & Heart Rate & $\begin{array}{c}\text { Body temperature } \\
\left({ }^{\circ} \mathrm{C}\right)\end{array}$ \\
\hline $\begin{array}{c}\text { Group 1+Group } 2 \\
\text { (n:16) } \\
\text { Mean } \pm \text { SD } \\
(\mathrm{CI})\end{array}$ & $\begin{array}{c}2018 \pm 173.45 \\
(1625-2235)\end{array}$ & $\begin{array}{l}0.17 \pm 0.01 \\
(0.15-0.19)\end{array}$ & $\begin{array}{c}40.3 \pm 2.38 \\
(34-44)\end{array}$ & $\begin{array}{c}30.5 \pm 0.89 \\
(30-32,5)\end{array}$ & $\begin{array}{c}190 \pm 6.64 \\
(180-204)\end{array}$ & $\begin{array}{c}38.8 \pm 0.10 \\
(38.5-39)\end{array}$ \\
\hline $\begin{array}{c}\text { Group 3+Group } 4 \\
\text { (n:17) } \\
\text { Mean } \pm \text { SD } \\
\text { (CI) }\end{array}$ & $\begin{array}{c}3494 \pm 132.69 \\
(3259-3709)\end{array}$ & $\begin{array}{l}0.25 \pm 0.01 \\
(0.25-0.27)\end{array}$ & $\begin{array}{c}45.4 \pm 2.47 \\
(42-51)\end{array}$ & $\begin{array}{c}37.2 \pm 1.34 \\
\quad(35-40)\end{array}$ & $\begin{array}{c}187 \pm 9.01 \\
(176-212)\end{array}$ & $\begin{array}{l}38.7 \pm 0.10 \\
(38.3-38.9)\end{array}$ \\
\hline $\begin{array}{c}\text { Group 5+Group } 6 \\
\text { (n:16) } \\
\text { Mean } \pm \text { SD } \\
(\mathrm{CI})\end{array}$ & $\begin{array}{c}4413 \pm 355.45 \\
(4045-4948)\end{array}$ & $\begin{array}{l}0.30 \pm 0.01 \\
(0.29-0.33)\end{array}$ & $\begin{array}{c}52.4 \pm 3.22 \\
(47-57)\end{array}$ & $\begin{array}{l}42.2 \pm 1.90 \\
\quad(40-45)\end{array}$ & $\begin{array}{c}189 \pm 10 \\
(180-196)\end{array}$ & $\begin{array}{l}38.7 \pm 0.10 \\
(38.4-38.8)\end{array}$ \\
\hline$P$ & $0.001 * * *$ & $0.001 * * *$ & $0.001 * * *$ & $0.001 * * *$ & 0.506 & 0.380 \\
\hline
\end{tabular}

SD: Standart deviation; CI: Confidence interval 95\%; *** $(P<0.001)$.

Table 2. Age related echocardiographic parameters.

\begin{tabular}{|c|c|c|c|c|}
\hline Value & $\begin{array}{c}\text { Group 1+Grup } 2 \\
\text { (n:16) } \\
\text { Mean } \pm \text { SD } \\
(\mathrm{CI})\end{array}$ & $\begin{array}{c}\text { Group 3+Group } 4 \\
\text { (n:17) } \\
\text { Mean } \pm \text { SD } \\
\text { (CI) }\end{array}$ & $\begin{array}{c}\text { Group 5+Group } 6 \\
\text { (n:16) } \\
\text { Mean } \pm \text { SD } \\
(\mathrm{CI})\end{array}$ & $P$ \\
\hline IVSTd (cm) & $\begin{array}{c}0.23 \pm 0.02^{\mathrm{a}} \\
(0.22-0.24)\end{array}$ & $\begin{array}{c}0.28 \pm 0.02^{\mathrm{b}} \\
(0.26-0.30)\end{array}$ & $\begin{array}{c}0.35 \pm 0.02^{\mathrm{c}} \\
(0.33-0.36)\end{array}$ & $0.001^{* * *}$ \\
\hline LVIDd (cm) & $\begin{array}{l}1.20 \pm 0.03^{\mathrm{a}} \\
(1.18-1.22)\end{array}$ & $\begin{array}{l}1.33 \pm 0.03^{b} \\
(1.31-1.35)\end{array}$ & $\begin{array}{l}1.41 \pm 0.08^{c} \\
(1.36-1.45)\end{array}$ & $0.001^{* * *}$ \\
\hline LVPWd (cm) & $\begin{array}{c}0.21 \pm 0.03^{\mathrm{a}} \\
(0.19-0.23)\end{array}$ & $\begin{array}{c}0.33 \pm 0.03^{b} \\
(0.31-0.35)\end{array}$ & $\begin{array}{c}0.45 \pm 0.05^{\mathrm{c}} \\
(0.42-0.47)\end{array}$ & $0.001^{* * *}$ \\
\hline IVSTs (cm) & $\begin{array}{c}0.30 \pm 0.04^{\mathrm{a}} \\
(0.28-0.32)\end{array}$ & $\begin{array}{c}0.43 \pm 0.04^{b} \\
(0.41-0.45)\end{array}$ & $\begin{array}{c}0.50 \pm 0.02^{\mathrm{c}} \\
(0.48-0.52)\end{array}$ & $0.001^{* * * *}$ \\
\hline LVIDs (cm) & $\begin{array}{c}0.77 \pm 0.05^{\mathrm{a}} \\
(0.74-0.80)\end{array}$ & $\begin{array}{c}0.90 \pm 0.04^{b} \\
(0.88-0.92)\end{array}$ & $\begin{array}{c}0.95 \pm 0.07^{\mathrm{c}} \\
(0.91-0.98)\end{array}$ & $0.001^{* * *}$ \\
\hline LVPWs (cm) & $\begin{array}{c}0.34 \pm 0.05^{\mathrm{a}} \\
(0.31-0.37)\end{array}$ & $\begin{array}{c}0.52 \pm 0.04^{b} \\
(0.49-0.54)\end{array}$ & $\begin{array}{c}0.59 \pm 0.04^{\mathrm{c}} \\
(0.56-0.61)\end{array}$ & $0.001^{* * *}$ \\
\hline EPSS (cm) & $\begin{array}{c}0.09 \pm 0.01^{\mathrm{a}} \\
(0.08-0.10)\end{array}$ & $\begin{array}{c}0.11 \pm 0.01^{b} \\
(0.10-0.12)\end{array}$ & $\begin{array}{c}0.15 \pm 0.01^{\mathrm{c}} \\
0.14-0.17)\end{array}$ & $0.001^{* * *}$ \\
\hline $\mathrm{EF} \%$ & $\begin{array}{l}63.50 \pm 3.94^{\mathrm{a}} \\
(61.39-65.60)\end{array}$ & $\begin{array}{l}58.58 \pm 2.82^{b} \\
(57.13-60.04)\end{array}$ & $\begin{array}{l}58.93 \pm 3.88^{b} \\
(56.86-61.01)\end{array}$ & $0.001^{* * *}$ \\
\hline $\mathrm{FS} \%$ & $\begin{array}{c}34.43 \pm 3.88 \\
(32.36-36.50)\end{array}$ & $\begin{array}{c}32.39 \pm 2.49 \\
(31.01-33.57)\end{array}$ & $\begin{array}{c}32.50 \pm 2.06 \\
(31.39-33.60)\end{array}$ & NS \\
\hline LAd (cm) & $\begin{array}{l}0.73 \pm 0.03^{\mathrm{a}} \\
(0.72-0.75)\end{array}$ & $\begin{array}{c}0.87 \pm 0.03^{b} \\
(0.85-0.89)\end{array}$ & $\begin{array}{l}1.13 \pm 0.05^{\mathrm{c}} \\
(1.10-1.16)\end{array}$ & $0.001^{* * *}$ \\
\hline LAd $(\mathrm{cm})$ & $\begin{array}{l}0.62 \pm 0.03^{\mathrm{a}} \\
(0.60-0.64)\end{array}$ & $\begin{array}{c}0.72 \pm 0.03^{b} \\
(0.70-0.74)\end{array}$ & $\begin{array}{c}0.96 \pm 0.07^{\mathrm{c}} \\
(0.91-1.00)\end{array}$ & $0.001^{* * *}$ \\
\hline $\mathrm{LAd} / \mathrm{AOd}$ & $\begin{array}{l}1.17 \pm 0.03 \\
(1.15-1.19)\end{array}$ & $\begin{array}{l}1.20 \pm 0.03 \\
(1.18-1.22)\end{array}$ & $\begin{array}{l}1.18 \pm 0.05 \\
(1.15-1.20)\end{array}$ & NS \\
\hline
\end{tabular}

SD: Standart deviation; CI: Confidence interval 95\%; $* * *(P<0.001), * *(P<0.01), *(P<0.05)$; NS: Not significant. Different superscript letters in the same line are given where significant differences $(P<0.05)$ were detected with post hoc comparisons among age groups ANOVA. 
Table 3. Echocardiographic parameters for each sex and age.

\begin{tabular}{|c|c|c|c|c|c|c|c|}
\hline Value & $\begin{array}{c}\text { Group } 1 \\
\text { Mean } \pm \text { SD } \\
(\mathrm{CI})\end{array}$ & $\begin{array}{c}\text { Group } 2 \\
\text { Mean } \pm \text { SD } \\
(\mathrm{CI})\end{array}$ & $\begin{array}{c}\text { Group } 3 \\
\text { Mean } \pm \text { SD } \\
(\mathrm{CI})\end{array}$ & $\begin{array}{c}\text { Group } 4 \\
\text { Mean } \pm \text { SD } \\
(\mathrm{CI})\end{array}$ & $\begin{array}{c}\text { Group } 5 \\
\text { Mean } \pm \text { SD } \\
\quad(\mathrm{CI})\end{array}$ & $\begin{array}{c}\text { Group } 6 \\
\text { Mean } \pm \text { SD } \\
(\mathrm{CI})\end{array}$ & $P$ \\
\hline $\operatorname{IVSTd}(\mathrm{cm})$ & $\begin{array}{c}0.22 \pm 0.02^{\mathrm{a}} \\
(0.20-0.24)\end{array}$ & $\begin{array}{c}0.25 \pm 0.01^{\mathrm{b}} \\
(0.23-0.26)\end{array}$ & $\begin{array}{c}0.29 \pm 0.01^{\mathrm{c}} \\
(0.27-0.30)\end{array}$ & $\begin{array}{c}0.27 \pm 0.03^{\mathrm{bc}} \\
(0.24-0.30)\end{array}$ & $\begin{array}{c}0.36 \pm 0.02^{\mathrm{d}} \\
(0.26-0.41)\end{array}$ & $\begin{array}{c}0.34 \pm 0.02^{\mathrm{d}} \\
(0.32-0.35)\end{array}$ & $0.001^{* * *}$ \\
\hline LVIDd $(\mathrm{cm})$ & $\begin{array}{l}1.21 \pm 0.03^{\mathrm{a}} \\
(1.18-1.23)\end{array}$ & $\begin{array}{l}1.18 \pm 0.03^{\mathrm{a}} \\
(1.15-1.22)\end{array}$ & $\begin{array}{c}1.34 \pm 0.03^{\mathrm{b}} \\
(1.31-1.38)\end{array}$ & $\begin{array}{c}1.32 \pm 0.03^{\mathrm{b}} \\
(1.29-1.34)\end{array}$ & $\begin{array}{l}1.43 \pm 0.07^{\mathrm{c}} \\
(1.31-1.44)\end{array}$ & $\begin{array}{l}1.44 \pm 0.07^{c} \\
(1.37-1.50)\end{array}$ & $0.001^{* * * *}$ \\
\hline LVPWd (cm) & $\begin{array}{c}0.20 \pm 0.02^{\mathrm{a}} \\
(0.18-0.21)\end{array}$ & $\begin{array}{c}0.23 \pm 0.03^{\mathrm{a}} \\
(0.19-0.26)\end{array}$ & $\begin{array}{c}0.35 \pm 0.03^{\mathrm{b}} \\
(0.31-0.38)\end{array}$ & $\begin{array}{c}0.32 \pm 0.01^{\mathrm{b}} \\
(0.31-0.33)\end{array}$ & $\begin{array}{c}0.45 \pm 0.04^{\mathrm{c}} \\
(0.41-0.49)\end{array}$ & $\begin{array}{c}0.44 \pm 0.05^{\mathrm{c}} \\
(0.39-0.49)\end{array}$ & $0.001^{* * * *}$ \\
\hline IVSTs $(\mathrm{cm})$ & $\begin{array}{c}0.29 \pm 0.04^{\mathrm{a}} \\
(0.25-0.33)\end{array}$ & $\begin{array}{c}0.32 \pm 0.02^{\mathrm{a}} \\
(0.30-0.34)\end{array}$ & $\begin{array}{c}0.42 \pm 0.04^{\mathrm{b}} \\
(0.38-0.46)\end{array}$ & $\begin{array}{c}0.44 \pm 0.03^{\mathrm{b}} \\
(0.41-0.46)\end{array}$ & $\begin{array}{c}0.49 \pm 0.02^{\mathrm{c}} \\
(0.48-0.51)\end{array}$ & $\begin{array}{c}0.50 \pm 0.02^{\mathrm{c}} \\
(0.48-0.52)\end{array}$ & $0.001^{* * * *}$ \\
\hline LVIDs $(\mathrm{cm})$ & $\begin{array}{c}0.77 \pm 0.06^{\mathrm{a}} \\
(0.73-0.82)\end{array}$ & $\begin{array}{c}0.77 \pm 0.05^{\mathrm{a}} \\
(0.72-0.82)\end{array}$ & $\begin{array}{c}0.91 \pm 0.03^{\mathrm{b}} \\
(0.87-0.94)\end{array}$ & $\begin{array}{c}0.89 \pm 0.04^{\mathrm{b}} \\
(0.85-0.92)\end{array}$ & $\begin{array}{c}0.99 \pm 0.04^{\mathrm{c}} \\
(0.97-1.02)\end{array}$ & $\begin{array}{c}0.98 \pm 0.04^{\mathrm{c}} \\
(0.95-1.02)\end{array}$ & $0.001^{* * * *}$ \\
\hline LVPWs (cm) & $\begin{array}{c}0.32 \pm 0.04^{\mathrm{a}} \\
(0.28-0.36)\end{array}$ & $\begin{array}{c}0.37 \pm 0.05^{\mathrm{a}} \\
(0.33-0.42)\end{array}$ & $\begin{array}{c}0.51 \pm 0.04^{\mathrm{b}} \\
(0.47-0.55)\end{array}$ & $\begin{array}{c}0.52 \pm 0.03^{\mathrm{b}} \\
(0.49-0.55)\end{array}$ & $\begin{array}{c}0.58 \pm 0.03^{\mathrm{c}} \\
(0.55-0.62)\end{array}$ & $\begin{array}{c}0.59 \pm 0.05^{\mathrm{c}} \\
(0.56-0.64)\end{array}$ & $0.001^{* * * *}$ \\
\hline EPSS $(\mathrm{cm})$ & $\begin{array}{c}0.09 \pm 0.01^{\mathrm{a}} \\
(0.08-0.09)\end{array}$ & $\begin{array}{c}0.09 \pm 0.01^{\mathrm{a}} \\
(0.08-0.09)\end{array}$ & $\begin{array}{c}0.11 \pm 0.01^{\mathrm{b}} \\
(0.10-0.11)\end{array}$ & $\begin{array}{c}0.11 \pm 0.01^{b} \\
(0.10-0.12)\end{array}$ & $\begin{array}{c}0.15 \pm 0.01^{\mathrm{c}} \\
(0.14-0.15)\end{array}$ & $\begin{array}{c}0.15 \pm 0.01^{\mathrm{c}} \\
(0.14-0.15)\end{array}$ & $0.001^{* * * *}$ \\
\hline $\mathrm{EF} \%$ & $\begin{array}{l}64.11 \pm 3.62^{a} \\
(61.32-66.89)\end{array}$ & $\begin{array}{c}62.71 \pm 4.49^{a} \\
(58.5-66.87)\end{array}$ & $\begin{array}{l}57.12 \pm 3.39^{b} \\
(54.21-59.90)\end{array}$ & $\begin{array}{l}57.88 \pm 1.36^{\mathrm{ab}} \\
(55.84-60.93)\end{array}$ & $\begin{array}{l}60.87 \pm 3.75^{\mathrm{ab}} \\
(57.73-64.01)\end{array}$ & $\begin{array}{l}59.00 \pm 3.11^{b} \\
(56.39-61.13)\end{array}$ & $0.001^{* * * *}$ \\
\hline $\mathrm{FS} \%$ & $\begin{array}{c}34.11 \pm 3.55 \\
(31.38-36.84)\end{array}$ & $\begin{array}{c}34.85 \pm 4.52 \\
(30.67-39.04)\end{array}$ & $\begin{array}{c}32.37 \pm 2.92 \\
(29.92-34.82)\end{array}$ & $\begin{array}{c}32.22 \pm 2.22 \\
(30.51-33.93)\end{array}$ & $\begin{array}{c}33.50 \pm 2.26 \\
(31.60-35.39)\end{array}$ & $\begin{array}{c}31.50 \pm 1.30 \\
(30.40-32.59)\end{array}$ & NS \\
\hline LAd $(\mathrm{cm})$ & $\begin{array}{c}0.75 \pm 0.03^{\mathrm{a}} \\
(0.72-0.78)\end{array}$ & $\begin{array}{c}0.72 \pm 0.02^{\mathrm{a}} \\
0.70-0.74)\end{array}$ & $\begin{array}{c}0.88 \pm 0.01^{\mathrm{b}} \\
(0.87-0.90)\end{array}$ & $\begin{array}{c}0.86 \pm 0.03^{\mathrm{b}} \\
(0.83-0.89)\end{array}$ & $\begin{array}{l}1.13 \pm 0.05^{\mathrm{c}} \\
(1.08-1.17)\end{array}$ & $\begin{array}{l}1.13 \pm 0.07^{\mathrm{c}} \\
(1.07-1.19)\end{array}$ & $0.001^{* * * *}$ \\
\hline $\mathrm{AOd}(\mathrm{cm})$ & $\begin{array}{c}0.64 \pm 0.04^{\mathrm{a}} \\
(0.61-0.67)\end{array}$ & $\begin{array}{c}0.60 \pm 0.02^{\mathrm{a}} \\
(0.58-0.62)\end{array}$ & $\begin{array}{c}0.73 \pm 0.02^{\mathrm{b}} \\
(0.71-0.75)\end{array}$ & $\begin{array}{c}0.71 \pm 0.03^{\mathrm{b}} \\
(0.69-0.74)\end{array}$ & $\begin{array}{c}0.96 \pm 0.08^{\mathrm{c}} \\
(0.88-1.03)\end{array}$ & $\begin{array}{c}0.96 \pm 0.07^{\mathrm{c}} \\
(0.89-1.02)\end{array}$ & $0.001^{* * * *}$ \\
\hline LAd/AOd & $\begin{array}{l}1.16 \pm 0.03 \\
(1.13-1.19)\end{array}$ & $\begin{array}{l}1.18 \pm 0.02 \\
(1.16-1.21)\end{array}$ & $\begin{array}{l}1.20 \pm 0.04 \\
(1.16-1.24)\end{array}$ & $\begin{array}{l}1.20 \pm 0.03 \\
(1.17-1.22)\end{array}$ & $\begin{array}{l}1.18 \pm 0.04 \\
(1.16-1.20)\end{array}$ & $\begin{array}{l}1.17 \pm 0.04 \\
(1.13-1.21)\end{array}$ & NS \\
\hline
\end{tabular}

SD:Standart deviation; CI: Confidence interval 95\%; ***(P<0.001),**(P<0.01),*(P<0.05); NS: Not significant. Different superscript letters in the same line are given where significant differences $(P<0.05)$ were detected with post hoc comparisons among age groups ANOVA.

\section{DISCUSSION}

New Zealand white rabbits are effective subjects for cardiological research because their size makes surgical manipulation of the heart more feasible than in other small laboratory animals, and they are cheaper to procure and maintain than dogs. Another benefit is that the kinetics of calcium and composition of myosin in the rabbits are similar to those in human myocardium [17].

The growth of the rabbits is affected by their genotype [22], sex [20], age [2,15], ambient temperature $[6,29]$, maintenance and feeding [12,23]. New Zealand rabbits are considered kittens in the first trimester after birth, completing puberty in their fifth month $[22,23]$. New Zealand rabbits complete their growth after eighth months under optimal conditions [26].

Echocardiography is an invaluable tool in the field of veterinary cardiology, serving as a non-invasive means of examining cardiac function and anatomy [3]. It is important to note that an echocardiographic examination is only part of a thorough cardiovascular evaluation, which should include clinical, electrocardiographic and radiographic examinations as well [18]. Animal models of cardiovascular disease have made such examinations increasingly significant tools in cardiovascular research [38]. Pet rabbits have been diagnosed with cardiac diseases, and an understanding of the animals' cardiac chamber dimensions is vital in assessing the diseases' severity and prognoses [21].

Reports describing congenital or acquired cardiac diseases in rabbits are being published more often [24,40]. It is increasingly recognised that aging results in changes in left ventricular (LV) function and structure that can play an important role in modulating cardiovascular responses to disease [31]. Animal models of cardiovascular diseases 
provide researchers with important insight into pathophysiological processes, and they are necessary tools for the development of new therapies [41].

Anaesthesia may have a profound effect on cardiac function, but there is little information available regarding its effect on cardiac function in rabbits [38]. Sedation can be achieved by administering 0.5 to $1 \mathrm{mg} / \mathrm{kg}$ midazolam intramuscularly with a minimal cardiovascular depression [36]. It has been reported the effects of midazolam preparations on the cardiovascular and autonomic nervous system can be overlooked [16]. In this study, $1 \mathrm{mg} / \mathrm{kg}$ of midazolam was used for sedation in rabbits.

Rabbit anemia may be classified by size mean cell volume $(\mathrm{MCH})$ and hemoglobin concentration (MCHC). Red blood cell (RBC) counts and hematocrit (HCT) vary with age, sex, and breed; however, most normal rabbits have Hct of $33 \%$ to $50 \%$. Hct, along with $\mathrm{MCH}$ and $\mathrm{MCHC}$, are calculated based on direct measurements in these instruments. Zehnder et al. [42] has reported that anemia changes echocardiographic parameters of the heart. Male and older animals tend to have higher values than female and younger animals [14]. On the other hand, Özkan et al. [27] found that the hematocrit value in New Zealand white rabbits did not change depending on sex.

Fontes-Sousa et al. [13] speculate that cardiac measurements do not increase with increased weight after rabbits reach maturity, but the authors did not have access to literature about age and body weight on growing echocardiographic parameters of New Zealand White Rabbits.

In dogs, the left ventricle internal diameter doubles during the first two months of growth $[9,37]$ and then grows slowly until the dogs' seventh month [10]. In Spanish foals, the left ventricular chamber increases faster its' diameter between three to six months of age in females [32]. In our study, left ventricular chambers and internal diameters increased in the three, six, and nine-month-old groups. However, IVSTd differed significantly between the sex groups of three-month-old rabbits. Age's effects on changes in ventricular and atrial geometry are still under debate [7].

EPSS is a distance between interventricular septum and the E point of the mitral valve is considered a practical and useful clinical index of the left ventricular inflow blood and hence of the left ventricular function [33]. Poser et al. [28] determined that EPSS is significantly correlated with BW and age in growing sheep. This is considered a functional systolic parameter which increases in cases of myocardial failure. In dogs, this is not influenced by sex, age, breed [19]. EPSS is significantly different among the different age groups in this study.

The cardiac indices obtained from the measured parameters (LAd:AOd, FS\%, and EF\%) were not influenced by body weight, age, or body surface area in beagles during their growth [10]. Among the functional parameters, the FS\% is not significantly correlated with BW, age, or HR in growing sheep [28]. In Dwarf Lops, French Lops and Alaskan rabbits Lad:AOd and FS\% were found to be independent of body weight, age, and sex, making them robust clinical parameters [5]. This study did not find FS\% to significantly vary with BW or age, which reinforces the practicality of these indices for determining cardiac function independently of other parameters, such as age or corporeal dimensions. However, EF\% has correlated negatively with body weight and age in dogs [8]. Our study showed a decrease in EF\% from the three to six-month-old rabbits and no significant difference between the six and nine-month groups. This might indicate the necessity of more periodical analysis of echocardiographic parameters.

This study demonstrates that age is a variable that should be considered for the establishment of accurate reference values for dimensional echocardiographic parameters in New Zealand rabbits. In contrast, sex appears to have no effect on echocardiographic parameters expect FS\%, Lad:AOd.

\section{CONCLUSION}

We have presented the normal echocardiographic parameters for growing New Zealand rabbits. Even if transthoracic echocardiography is a challenging technique due to a poor acoustic window, it represents the simplest and easiest tool for assessing cardiovascular function for research purposes in growing rabbit.

\section{MANUFACTURERS}

${ }^{1}$ Roche Hellas S.A. Alamanas, Greece.

${ }^{2}$ Mindray Bio-Medical, Electronics. Shenzhen, China.

${ }^{3}$ SPSS Inc. Chicago, IL, USA.

Funding. This study (It is part of the unpublished $\mathrm{PhD}$ thesis) was supported by the University of Adnan Menderes Scientific Research Projects Committee (VTF-13015).

Acknowledgments. The authors would like to thank special person Prof. Dr. Kathleen McEntee her help and guidance. 
Ethical approval. This study is part of the first author's $\mathrm{PhD}$ thesis. This study was approved by our Institutional Ethics Committee with number of (B.30.2.ADÜ/050.04/2012/069)
Declaration of interest. The authors report no conflicts of interest. The authors alone are responsible for the content and writing of the paper.

\section{REFERENCES}

1 Al-Haidar A., Farnir F., Deleuze S, Sandersen C.F., Leroux A.A., Borde L., Cerri S. \& Amory H. 2013. Effect of breed, sex, age and body weight on echocardographic measurements in the equine species. Research in Veterinary Science. 95: 255-260.

2 Bhasin V., Shastry V.R.B., Singh D., Gulyani R., Malhi R.S., Kishore K., Singh R.N., Lahri S.S., Rai R.B. \& Das P.K. 1989. Performance of broiler rabbits in a subtemperate Himalayan region. Journal of Applied Rabbit Research. 12: 263-265.

3 Boon J. 2011. The two dimensional echocardiographic exam. In: Boon J. (Ed). Veterinary Echocardiography. Chichester: Jon Willey \& Sons, pp.53-138.

4 Boluyt M.O., Converso K., Hwang H.S., Mikkor A. \& Russell M.W. 2004. Echocardiographic assesment of ageassociated changes in systolic and diastolic function of the female rat F344 rat heart. Journal of Applied Physiology. 96: 822-828.

5 Casamian-Sorrosal D., Saunders R., Browne W.J., Elliott S. \& Fonfara S. 2014. M-mode, two-dimensional and Doppler echocardiographic findings in 40 healthy domestic pet rabbits. Journal of Veterinary Cardiology. 16: 101-108.

6 Colin M. 1990. Rabbit breeding problems in summer. Rivista di Coniglicoltura. 27: 11-19.

7 Daimon M., Watanbe H., Abe T., Hirata K., Hozumi T., Ishii K., Ito H., Iwakura K., Izumi C., Matsuzaki M., Minagoe S., Abe H., Murata K., Nakatani S., Negishi K., Yoshida K., Tanabe K., Tanaka N., Tokai K. \& Yoshikawa J. 2008. Normal values of echocardiographic parameters in relation to age in a healthy Japanese population: The JAMP study. Circulation Journal. 72: 1859-1866.

8 Della Torre P.K., Kirby A.C., Church D.B. \& Malik R. 2000. Echocardiographic measurements in greyhounds, whippets and Italian greyhounds - dogs with similar conformation but different size. Australian Veterinary Journal. 78: 49-55.

9 De Heer L.M., Buddle R.P., Vonken E.J., Baaijens F.P., Gründeman P.F., Van Herwerden L.A., Hoerstrup S.P. \& Kluin J. 2011. Computed tomography detects tissue formation in a stented engineered heart valve. The Annals of Thoracic Surgery. 92: 344-345.

10 Diez-Prieto I., García-Rodríguez M.B., Ríos-Granja M.A., Cano-Rábano M.J., Peña-Penabad M. \& Pérez-García C.C. 2010. M-mode echocardiographic changes in growing beagles. Journal of the American Association for Laboratory Animals Science. 49: 31-35.

11 Du Bois D. \& Du Bois E.F. 1989. A formula to estimate the approximate surface area if height and weight be known. Nutrition. 5: 303-311.

12 El-Sayiad G.H.A., Yamani K.O., Tawfeek M.I. \& Yassin H.M. 1993. Some traits of doe and young rabbits as affected by breed, parity and diet supplementation under Egypt conditions. Egyptian Journal of Rabbit Science. 3: 81-90.

13 Fontes-Sousa A.P., Brás-Silva C., Moura C., Areias J.C. \& Leite-Moreira A.F. 2006. M-mode and doppler echocardiographic reference values for male New Zealand white rabbits. American Journal of Veterinary Research. 67: 1725-1729.

14 Jenkins J.R. 2008. Rabbit diagnostic testing. Journal of Exotic Pet Medicine. 17: 4-15.

15 Joy A.D., Jose M.T. \& Prabhakaran P. 1985. Carcass characteristics of American Chinchilla crossbred rabbits. Kerala Journal of Veterinary Science. 16: 29-32.

16 Green C.J. 1975. Neuroleptanalgesic drug combinations in the anaesthetic management of small laboratory animals. Laboratory Animals. 9: 161-178.

17 Hasenfuss G. 1998. Animal models of human cardiovascular disease, heart failure and hypertrophy. Cardiovascular Research. 39: 60-76.

18 Kienle R.D. \& Thomas W.P. 1995. Echocardiography. In: Nyland T.G. \& Mattoon J.S. (Eds). Veterinary Diagnostic Ultrasound. Philadelphia: Saunders, pp.198-256.

19 Kirberger R.M. 1991. Mitral valve E point to ventricular septal separation in the dog. Journal of the South African Veterinary Association. 62: 163-166.

20 Kraus A.L., Weisbroth S.H., Flatt R.E. \& Brewer N. 1977. Biology and diseases of rabbits. New York: Academic Press, 483p. 
21 Kriz N.G., Hodgson D.R. \& Rose R.J. 2000. Changes in cardiac dimensions and indices of cardiac function during deconditioning in horses. American Journal of Veterinary Research. 61: 1553-1560.

22 Mach K. \& Safarova P. 1988. Purebreeding and commercial crossing of broiler type rabbits. Scientia Agricultura Bohemos. 20: 211-216.

23 Maertens L. \& De Groote G. 1990. Comparison of feed intake and milk yield of does under normal and high ambient temperature. The Journal of Applied Rabbit Research. 13: 159-162.

24 Martin M.W., Darke P.G. \& Else R.W. 1987. Short communication: congestive heart failure with atrial fibrillation in a rabbit. Veterinary Record. 24: 570.

25 Mora C., Fontes-Sousa A.P., Teixeira-Pinto A., Areias J.C.C. \& Leite-Moreira A.F. 2009. Agreement between echocardiographic techniques in assessment of the left ventricular myocardial performance index in rabbits. American Journal of Veterinary Research. 70: 464-471.

26 Nazlıgül A. 1998. Laboratory Animal Breeding. Aydın: Adnan Menderes University Publications, pp.12-23.

27 Özkan C., Kaya A. \& Akgül Y. 2012. Normal values of haematological and some biochemical parameters in serum and urine of New Zealand White rabbits. World Rabbit Science. 20: 253-259.

28 Poser H., Semplicini L., De Benedictis G.M., Gerardi G., Contiero B., Maschietto N., Valerio E., Milanesi O., Semplicini A. \& Bernardini D. 2013. Two-dimensional, M-mode and Doppler-derived echocardiographic parameters in sedated healthy growing female sheep. Laboratory Animals. 47: 194-202.

29 Rafai P. \& Papp Z. 1984. Temperature requirement of (rabbit) does for optimal performance. Archiv Fur Experimentelle Veterinarmedizin. 38: 450-457.

30 Rishniw M. \& Erb H.N. 2000. Evaluation of four 2-dimensional echocardiographic methods of assessing left atrial size in dogs. Journal of Veterinary Internal Medicine. 14: 429-435.

31 Ruan Q. \& Nagueh S.F. 2005. Effect of age on left ventricular systolic function in humans: a study of systolic isovolumic acceleration rate. Experimental Physiology. 90: 527-534.

32 Rovira S. \& Muñoz A. 2009. Two-dimensional and M-mode echocardiographic measurements and indexes of cardiac function in Spanish colts and fillies of different age. Journal of Veterinary Medical Science. 71: 957-964.

33 Rovira S., Muñoz A. \& Rodilla V. 2009. Allometric scaling of echocardiographic measurements in healthy Spanish foals with different body weight. Research in Veterinary Science. 86: 325-331.

34 Sahn D.J., Maria A., Kisslo J. \& Weyman A. 1978. Recommendations regarding quantitation in M-mode echocardiography: results of a survey of echocardiographic measurements. Circulation. 58: 1072-1083.

35 Schille S. \& Skrodzki M. 1999. M-mode echocardiographic reference values in cats in the first three months of life. Veterinary Radiology Ultrasound. 40: 491-500.

36 Silva E.F., Borboleta L.R., Telles T.C., Fonseca V.B. \& Melo M.M. 2011. Echocardiographic evaluation in rabbits: association of midazolam and ketamine. Arquivo Brasileiro de Medicina Veterinária e Zootecnia. 63: 112-117.

37 Sisson D. \& Schaeffler D. 1991. Changes in linear dimensions of the heart, relative to body weight, as measured by M-mode echocardiography in growing dogs. American Journal of Veterinary Research. 52: 1591-1596.

38 Stypmann J., Engelen M.A., Breithardt A.K., Milberg P., Rothenburger M., Breithardt O.A., Breithardt G., Eckardt L. \& Cordula P.N. 2007. Doppler echocardiography and tissue Doppler imaging in the healthy rabbit: differences of cardiac function during awake and anaesthetised examination. International Journal of Cardiology. 115: 164-170.

39 Teichholz L.E., Kreulen T., Herman M.V. \& Gorlin R. 1976. Problems in echocardiographic volume determinations: Echocardiographic-angiographic correlations in the presence of absence of asynergy. American Journal of Cardiology. 37: 7-11.

40 Voros K., Seehusen F., Hungerbuhler S., Meyer-Lindenberg A. \& Hoeh Von Der N. 2011. Ventricular septal defect with aortic valve insufficiency in a New Zealand white rabbit. Journal of the American Veterinary Medical Association. 47: 42-49.

41 Zaragoza C., Gomez-Guerrero C., Martin-Ventura J.L., Blanco-Colio L., Lavin B., Mallavia B., Tarin C., Mas S., Oritz A. \& Eqido J. 2011. Animal models of cardiovascular diseases. Journal of Biomedicine and Biotechnology. 1-13. doi: $10.1155 / 2011 / 497841$.

42 Zehnder C., Zuber M., Sulzer M., Meyer B., Straumann E., Jenzer H.R. \& Blumberg A. 1992. Influence of longterm amelioration of anemia and blood pressure control on left ventricular hypertrophy in hemodialyzed patients. Nephron. 61(1): 21-25. 